\title{
Abnormal Branch of External Iliac Artery in the Iliac Fossa
}

\author{
Rama Anormal de la Arteria Ilíaca Externa en la Fosa Ilíaca \\ Satheesha Nayak B.
}

\begin{abstract}
NAYAK, B. S. Abnormal branch of external iliac artery in the iliac fossa. Int. J. Morphol., 26(2):445-446, 2008.
SUMMARY: An abnormal artery arising from external iliac artery was found during routine dissection class for medical undergraduates. The artery took its origin from the external iliac artery midway between its origin from common iliac and termination as femoral artery. The abnormal artery divided into two branches; an ascending and a descending. The ascending branch supplied iliacus and iliac crest. The descending branch entered the femoral triangle by passing behind the femoral sheath. It supplied the muscles of femoral triangle and anastomosed with medial circumflex femoral artery. The knowledge of this variation may be of use for surgeons doing surgery of femoral hernia.
\end{abstract}

KEY WORDS: External iliac artery; Anatomical variation; Iliac fossa.

\section{INTRODUCTION}

External iliac artery is the larger terminal branch of the common iliac artery. It runs down across the iliac fossa and exits the pelvis by passing deep to the inguinal ligament. It continues as femoral artery at midinguinal point. It is accompanied by the external iliac vein on its medial side. The external iliac artery normally gives two named branches; the inferior epigastric artery and the deep circumflex iliac arteries. Apart from the above two branches, it gives small branches to psoas major muscle and neighboring lymph nodes.

\section{CASE REPORT}

During routine dissections for medical undergraduates, an abnormal branch from external iliac artery was noted in a male cadaver aged approximately 60 years. The variation was on the left side and was unilateral. The abnormal artery was of medium size and took its origin midway between the origin and termination of the external iliac artery. It coursed downwards and to the left in the iliac fossa for about an inch and then divided into an ascending and a descending branches (Fig. 1). The ascending branch coursed upwards and to the left and reached the iliac crest. It supplied the iliacus muscle and the iliac crest.
The descending branch coursed downwards and medially behind the external iliac artery and femoral sheath to reach the femoral triangle. In the femoral triangle it gave branches to the muscles in the floor of femoral triangle and anastomosed with the medial circumflex femoral artery. There is no evidence in the literature for such an abnormal branch from the external iliac artery.

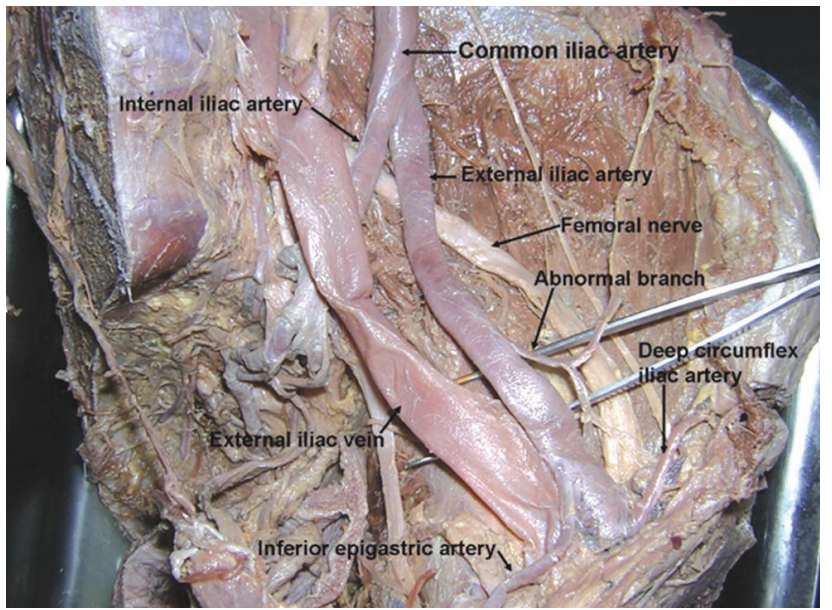

Fig. 1. Photograph of the dissection of the left iliac fossa with abnormal branch of external iliac artery. 


\section{DISCUSSION}

Variations of external iliac artery are rare. The artery may be longer or shorter than its normal length. When it is longer, it will be tortuous. Sometimes it may directly arise from aorta (Mansfield \& Howard, 2005). It may be much smaller in diameter when the femoral artery arises from the inferior gluteal artery or internal iliac artery. In such cases, the external iliac artery ends in the profunda femoris artery. Occasionally the obturator artery, superficial external pudendal artery or profunda femoris artery might arise from external iliac artery as its abnormal branch (Bergman et al., 1988). A loop of external iliac artery into the lesser pelvis has been observed by von Hochstetter (1989). Such loop is said to cause complications in total hip replacement surgeries.
Sarikcioglu \& Sindel (2002) have reported the origin of obturator artery from external iliac and the inferior epigastric from femoral artery. Bilgiç \& Sahin (1997) observed a common trunk arising from external iliac and dividing into obturator, inferior epigastric and profunda femoris arteries.

There are no reports on an artery similar to the one we are reporting here. The descending branch of the abnormal artery is in a dangerous position behind the femoral sheath. It also passed down close to the hip joint. The artery may cause a lot of bleeding if it is cut during surgeries of femoral hernia or surgeries of hip joint. This case may be of special interest to the surgeons in general and orthopedic surgeons.

NAYAK, B. S. Rama anormal de la arteria ilíaca externa en la fosa ilíaca. Int. J. Morphol., 26(2):445-446, 2008.

RESUMEN: Una variación arterial proveniente de la arteria ilíaca externa fue encontrada durante una disección de rutina en Medicina de pregrado. La arteria se originaba de la arteria ilíaca externa a mitad de camino entre su origen desde la arteria ilíaca común y su terminación, la arteria femoral. La arteria se dividía en dos ramas: ascendente y descendente. La rama ascendente suministraba la irrigación al músculo ilíaco y a la cresta ilíaca. La rama descendente entraba en el trígono femoral pasando por detrás de la vaina femoral y daba la irrigación a los músculos del trígono femoral, anastomosándose con la arteria circunfleja femoral medial. El conocimiento de esta variación puede ser de utilidad para los cirujanos que realizan cirugía de hernia femoral.

PALABRAS CLAVE: Arteria ilíaca externa; Variación anatómica; Fosa Ilíaca.

\section{REFERENCES}

Bergman, R. A.; Thompson, S. A.; Afifi, A. K. \& Saadeh, F. A. Compendium of Human Anatomic variation: catalog, Atlas and World Literature. Urban and Schwazenberg, Baltimore and Munich, 1988.

Bilgiç, S. \& Sahin, B. Rare arterial variation: a common trunk from the external iliac artery for the obturator, inferior epigastric and profunda femoris arteries. Surg. Radiol. Anat., 19(1):45-7, 1997.

Mansfield, A. O. \& Howard, J. M. Absence of both common iliac arteries. A case report. Anat. Rec., 150(4):363-4, 2005.

Sarikcioglu, L. \& Sindel, M. Multiple vessel variations in the retropubic region. Folia Morphol. (Warsz), 61(1):43$5,2002$.

von Hochstetter, A. H. The "lesser pelvic loop" of the external iliac artery. Surg. Radiol. Anat., 11(1):23-7, 1989.
Correspondence to:

Satheesha Nayak B.

Associate Professor of Anatomy

Melaka Manipal Medical College (Manipal Campus)

Madhav Nagar, Manipal

Udupi District 576104

Karnataka State

INDIA

Email: nayaksathish@yahoo.com

Received: 03-12-2007

accepted: 27-05-2008 